\title{
From Strategic Marine Planning to Project Licences - Striking a balance between predictability and adaptability in the management of aquaculture and offshore wind farms
}

\author{
Sigrid Eskeland Schütz, University of Bergen (Norway)
}

Anne-Michelle Slater, University of Aberdeen (Scotland)

\begin{abstract}
Renewable energy and sustainable food production are high on the international agenda, as is the prospect of increasing activity northwards to Arctic waters. In this article, we review core elements of the marine governance systems for aquaculture facilities and offshore wind farms in Norway and Scotland. Management of these sectors through strategic planning, marine spatial planning and licensing systems furthers rule of law values such as stability and predictability, making investment less risky. The review illustrates how the governance systems also facilitates flexibility and adaptability, balancing predictability considerations against the need to adapt management to natural and economic changes and innovative technologies, or even effective multi-use. This article discusses how endeavours have been made to strike a balance between predictability and adaptability in these sectors in Norway and Scotland. The study of marine management regimes in the Arctic and northern parts of the Temperate Northern Atlantic, and the values underpinning these regimes, thus provides lessons for the future of the Arctic.
\end{abstract}

Sub-themes: Arctic, Northern Atlantic. Marine governance, marine management, strategic marine planning, marine spatial planning, licence. Local self-government. Aquaculture. Offshore wind farms. Adaptability.

Rule of law values: Stability, predictability. 


\section{Renewable energy and sustainable food production in Norway and Scotland}

New technological possibilities and pressure on onshore areas and resources are increasing interest in moving industries such as food and renewable energy production offshore northwards to Arctic waters beyond $66^{\circ}$ (Arctic Circle). Norway and Scotland are at the forefront of developing this activity in Europe's sector of the Arctic Ocean and the northernmost part of the Atlantic. However, the dynamic and fragile ecosystems in this area and the harsh conditions in these waters are challenging for marine management. This calls for a review of the core elements of the marine governance systems in Norway and Scotland based on a functional approach, comparing structures and rules that fulfil the same functions in the national systems. ${ }^{1}$ The aim is to consider the management from a legal values perspective: ${ }^{2}$ Is the system capable of facilitating flexibility and adaptability, while at the same time ensuring stability and predictability? Two sectors have been chosen to illustrate how balancing predictability and adaptability plays out in mature versus emerging industries; the offshore aquaculture sector and offshore wind farms, respectively.

When looking at core elements of the management systems, the multiple levels of the systems cannot be ignored. This article will examine, from a legal values perspective, the management of aquaculture and offshore wind farms through strategic marine plans (s. 3), marine spatial planning (MSP) (s. 4) and licensing (s. 5). This perspective builds on the assumption that how the values of predictability and adaptability are balanced does not just depend on the separate parts, such as the licence system, but also on the context within which the parts operate in the overall management system.

Norway manages aquaculture and offshore wind farms based on an existing legal framework, although no wind farms are currently under construction. Aquaculture is pursued both in the Barents Sea, the Norwegian Sea and the North Sea. The Barents Sea is within the Arctic Circle, but in the context of Marine Ecoregions, the coastal areas of Northern Norway and Finnmark belongs not to the 'Arctic' ecoregion, but the 'Temperate Northern Atlantic'. ${ }^{3}$ Scotland is outside the Arctic Circle, being situated in the Temperate Northern Atlantic. The development of both aquaculture and offshore windfarms is ongoing in the Scottish marine sector, with, for example, the Beatrice Wind Farm at latitude $58^{\circ}$ now under construction. ${ }^{4}$ Norway and Scotland represent northern jurisdictions in Europe with comprehensive marine management systems for energy and food production. ${ }^{5}$ The production takes place in a comparable ecology and harsh climate, and these natural conditions continues into the parts of the Temperate Northern Atlantic that are situated within the Arctic Circle. It is therefore probable that the study of these systems can provide lessons for the Arctic. The Arctic countries also represent a meeting point of common law and civil law systems. ${ }^{6}$ Norway is a civil law country and Scotland a mixed system of common and civil law. ${ }^{7}$ Comparison across legal systems will inevitably be important in forthcoming studies of circumpolar jurisdiction.

\section{Predictability vs adaptability}

Are the marine governance systems capable of furthering stability and predictability, while at the same time providing adaptability? The contradictions at the root of the values of predictability and adaptability indicate a need to strike a balance. From the viewpoint of predictability, the question could be re-phrased as whether the system adequately protects legitimate expectations, e.g. an expectation of starting up or continuing to operate a wind farm in a marine area. From the viewpoint of adaptability, the question could be whether the system has adequate flexibility to 
manage the dynamics of ecosystems and human impact, for example to change the terms of an aquaculture licence due to unforeseen environmental impacts. Before discussing this, it will be useful to clarify how we understand the concepts of predictability and adaptability.

Globally, aquaculture is making an important contribution to food security, ${ }^{8}$ and offshore wind has great potential to contribute to energy production. ' Such 'blue growth' could promote the achievement of the 2030 targets for the UN Sustainable Development Goals (SDG): ${ }^{10}$ Zero hunger (SDG no 2), Affordable and clean energy (7), Industry, innovation and infrastructure (9), and Climate action (13), among others. These industries are not without environmental impact, however. Balancing aquaculture or new clean energy production with ecological and marine space impacts is manifestly a political issue, but it is still framed by legal values and substantive and procedural rules. The value of stability and predictability is a fundamental rule of law value. ${ }^{11}$ In a "thin" sense, rule of law protects liberty, where citizens know "the full range of conduct they can engage in without fear of being subject to government interference or sanction". ${ }^{12}$ Here we relate to the "thicker" definition of rule of law, including references to fundamental rights, ${ }^{13}$ protecting private interests and investments, and thus promoting investment in aquaculture and offshore wind.

By stability and predictability we mean the value, and protection of established rights, such as a contract, an aquaculture licence or a property right to a wind farm, which are fundamental values in the legal systems of both Norway and Scotland. As signatories to the 1950 European Convention on Human rights, ${ }^{14}$ property is protected by Article 1 of Protocol No $1 .{ }^{15}$ Under the convention, the concept of 'possessions" "has an autonomous meaning which is not limited to the ownership of physical goods and is independent from the formal classification in domestic law: certain other rights and interests constituting assets can also be regarded as "property rights". ${ }^{16}$ It is not limited to existing possessions "but may also cover assets, including claims, in respect of which the applicant can argue that he has at least a reasonable and legitimate expectation of obtaining effective enjoyment of a property right" ${ }^{17}$ still a "legitimate expectation of being able to continue having peaceful enjoyment of a possession must have a 'sufficient basis in national law"'. ${ }^{18}$ While there is no codified constitution in the United Kingdom, ${ }^{19}$ the constitutional position in both Norway and Scotland is that encroachment on private rights should be democratically rooted in formal legislation by the parliament. Thus, infringements by the authorities against the individual must be grounded in the law. ${ }^{20}$ Likewise, the constitutional position is that no law may be given retroactive effect. ${ }^{21}$ The requirement for formal legislation - rule of law in a 'thin' sense - is a key to ensuring predictability.

In the overall management system - marine policy and strategic plans, the allocation of areas to certain activities, and detailed plans and licences - expectations are created according to the law, such as the possibility of applying for a licence for a wind farm in a specific area. What expectations are protected, and when, depends on the specifics of the management systems of Norway and Scotland, as well as on whether any policy-based or legal protection is granted. ${ }^{22}$ In the value of predictability we also include a more vague notion of due protection of legitimate expectations.

Besides traditional rule of law values, the environmental challenges resulting from industrialisation have introduced values of environmental justice to the legal systems, such as strategies for 'sustainable development' and an 'ecosystem approach', which are widely endorsed today in legal instruments in both Norway and Scotland..$^{23}$ The structure and functioning of marine ecosystems within their own ecological boundaries, sustainable use and maintenance of ecosystem integrity are 
at the core of the ecosystem approach, together with a holistic approach that integrates various objectives. ${ }^{24}$ Because they are complex adaptive systems, the behaviour of the systems becomes rather unpredictable, ${ }^{25}$ and the approach acknowledges that management "must recognise that change is inevitable". ${ }^{26}$ Adaptive management has been recognised as a method for managing complex ecological systems; management policies should be flexible and should incorporate new information as it becomes available. ${ }^{27}$ This is the context in which adaptability in management is understood in the following.

Proceeding from these general reflections on predictability and adaptability, we can ask what specific tensions emerge or are present when endeavouring to balance predictability and adaptability in the management of aquaculture and offshore wind power?

A licence is of economic value to the licensee. ${ }^{28}$ The value of predictability requires that due protection should be given to established rights, in the form of a licence, and the terms it sets for the activity. The value of adaptability, on the other hand, could imply a need for changes in the terms due, for example, to unforeseen changes in the natural conditions. These values have implications for legislation on amending or revoking existing licences; the legal implications of a permit matter "from a resilience and flexibility point of view". ${ }^{29}$ It is more difficult to cope with changes if licences can hardly be reviewed or revoked at all than if this is a possibility, albeit in regulated form. ${ }^{30}$ Regulating the conditions that determine production capacity, the right to continue the activity or reduce or close down production, sale, transfer and mortgage of the licence etc. gives the licensee predictability as regards the terms for her economic investments.

The allocation of licences to marine activity can lead to unforeseen cumulative impacts, a lack of coordination and inefficient use of marine space and resources. One answer to these challenges has been the development of marine spatial plans, dedicating areas to specific uses, i.e. zoning. ${ }^{31}$ Spatial plans are living instruments that can be altered in cyclical processes of, for instance, four years' duration, and adapted to changing conditions, promoting the value of adaptive management. How can an MSP promote adaptability, but at the same time ensure predictability for established industries in the area? Could, for example, an established aquaculture site be reserved as a marine protected area in a later marine spatial plan?

At the most strategic policy level of planning are management plans for Large Marine Ecosystems, that can be altered in cyclical processes, based on an ecosystem, and thus an adaptive, approach. ${ }^{32}$ The degree of tension here between adaptability and predictability depends on the content of strategic plans and their legal implications for succeeding marine spatial plans and private rights in the area. An assumption is that this strategic policy level of planning should not infringe private rights and thus the value of predictability. This needs to be examined further, however, and it is discussed in the following.

\section{Strategic planning of large marine ecosystems}

Ecosystem-based management is suggested as a way of improving marine management. ${ }^{33}$ Norway and Scotland have implemented strategic planning of large marine ecosystems (LME) ${ }^{34}$ and 'planning' comprises both the processes and resulting maps and documents; in Norway they are called 'integrated management plans', in Scotland 'marine plans'. The plans aim to fulfil international obligations, such as those under OSPAR ${ }^{35}$ and EU/EEA law, ${ }^{36}$ and to adhere to the values of the ecosystem approach. The adaptive approach is evident in the cyclical strategic 
planning of LMEs, where new knowledge is gained about the state of the ecosystem and important habitat structures, pollution or the impact of human activity. They are used to improve the management process and provide a knowledge base for implementing new measures. ${ }^{37}$ When plans are revised, up-to-date knowledge and insights into the ecosystem, activity and impacts are taken into consideration, resulting in the adaptation of analyses, mapping, zoning or proposed management measures. It could be argued that such adaptive planning reduces predictability for private parties who have planned activity or who already engage in activity in the area. On the other hand, strategic planning of LMEs gives marine stakeholders clarity about the fundamental premises for management, as it clarifies that management will be based on up-to date knowledge, will be holistic - taking all impacts on the LME into consideration - and seek to achieve international and national management objectives. In this perspective, it can be argued that strategic planning of LMEs promotes predictability.

Norway has integrated management plans for the Norwegian part of three large marine planning regions: the North Sea, the Norwegian Sea, and, in waters within the Arctic Circle, the Barents Sea - Lofoten area (LME plans). ${ }^{38}$ The area covered by the (updated) Barents Sea plan ${ }^{39}$ is based on ecological and administrative considerations, ${ }^{40}$ and extends from the sea area beyond the baselines. ${ }^{41}$ It is stated in the plans that they aim to achieve holistic and ecosystem-based management. ${ }^{42}$ For Scotland, the 'Marine Acts ${ }^{43}$ have set out a three-tiered approach to the development of marine planning: UK, Scotland-wide and regional. The UK administrations share a common vision set out in the 2011 UK Marine Policy Statement, ${ }^{44}$ promoting an ecosystem approach. ${ }^{45}$ As opposed to Norway, where LME plans have no legal foundation, ${ }^{46}$ there is a statutory requirement to produce a marine plan for Scottish waters. ${ }^{47}$ Scotland's National Marine Plan (SNMP) 2015 covers all policy areas, ${ }^{48}$ and extends $200 \mathrm{~nm}$ from the baseline. The Scottish plan encompasses the Scottish part of both the large marine ecoregions of the 'North Sea' and the 'Celtic Sea', ${ }^{49}$ and it covers inshore waters. ${ }^{50}$ In both countries, the plans draw on a range of existing plans and strategies for particular locations in specific sectors, and it is the Government that is responsible for the plans, which are discussed and approved in the respective parliaments.

This leads to the question of whether LME plans affect the aquaculture and offshore wind sectors and, if so, do the plans undermine predictability for stakeholders who rely on established Marine Spatial Plans or issued licences? Marine Spatial Plans are in general, as we return to in sec. 4, more detailed in distribution of sea-use compared to LME plans. Norwegian LME plans are primarily intended to guide the public management of different marine sectors through more detailed, sectorspecific management instruments. ${ }^{51}$ Likewise, the SNMP is expected to guide the regional marine plans that are currently being developed. ${ }^{52}$ As policy instruments, the LME-plans do no impose legally binding restrictions on private stakeholders, and combined with their strategic level, the plans can thus not affect expectations of predictability. At the same time, it is argued in the Barents Sea plan that it aims to contribute to the clarity of overall frameworks, coordination and priorities in the management of the sea areas and to "increase predictability and enhanced coexistence between marine industries". ${ }^{53}$ Predictability in this context is clearly not related to whether plans impose legally binding restrictions, but could be understood as described above, i.e. as clarifying the fundamental premises for management; management will be based on up-to date knowledge, will be holistic and seek to achieve international and national management objectives. Some further details from the sectors could shed light on the implications of LME plans. 
A general notion is that in both Norway and Scotland, aquaculture have developed in a bottom-up process, ${ }^{54}$ where the ecosystem approach was first introduced after the industry had matured. Still expected infringements on existing industry are partly averted, due to the protection of national wild salmon fjords and rivers in Norway in $2006-2007^{55}$ and the early ban on any aquaculture facilities on the north and east coasts of Scotland. ${ }^{56}$ These early precautionary measures steered the industry away from the most conflict-ridden sites, making later policies and strategies able to respect established private rights and thus provide predictability.

Until now, aquaculture production in Norway has been located inside the baselines. ${ }^{57}$ The question of whether LME plans undermine predictability in the aquaculture sector is not relevant because of the landward limitations of the Norwegian LME plans. The plans are simply not tools in the sector.

Since the Scottish strategic planning area encompasses the fjords and coastal waters all the way to the shoreline, they are a tool for aquaculture management. For the west coast, the inclusion of coastal waters means that the SNMP provides a general strategic policy for aquaculture. ${ }^{58}$ The Scottish Government supports growing the sector sustainably, ${ }^{59}$ but increasingly there is recognition of the serious challenges faced by the aquaculture industry in relation to fish welfare, climate change and environmental impacts. ${ }^{60}$ One objective of the SNMP is to provide a proportionate and transparent regulatory framework, to improve investment and business confidence, and reduce its environmental impact by identifying areas where sustainable aquaculture growth is optimal. The SNMP acknowledges that finfish and shellfish cultivation depends on farms being situated in locations where the water quality is good and the current flow allows the growth of healthy fish and shellfish. ${ }^{61}$ Since the SNMP was adopted, Locational Guidelines for the Authorisation of Marine Fish Farms in Scottish Waters have identified further areas for development. ${ }^{62}$ This divides the marine area from the shoreline to three nautical miles beyond the baselines into three categories, where there is a presumption against further fish farm development (Category 1), ${ }^{63}$ where a degree of caution should be exercised (2), and where fish farm development is likely to be acceptable (3). ${ }^{64}$ Marine Scotland Science has identified areas of opportunity and constraint in updates to the Locational Guidelines, ${ }^{65}$ and strategic land use planning policy is also relevant. ${ }^{66}$ Notwithstanding a streamlining of regulatory processes for aquaculture in the past in Scotland, the ongoing challenges faced by the industry combined with the incremental increase in regulatory requirements has resulted in a complex regime, that might benefit from a clearer relationship between the strategic planning of large ecosystems and marine spatial planning.

The Norwegian Barents Sea plan encompasses offshore wind, even where suggested areas for wind farms are placed on the landward side of the baselines. This illustrates a pragmatic approach to using the baselines as demarcation lines in LME planning, which is in accordance with the ecosystem approach. ${ }^{67}$ As for offshore wind farms, the Norwegian Ocean Energy Act (OEA) provides for a formal MSP process for 'the opening of areas' for offshore wind development, with a view to the granting of licences, see section $3 .^{68} \mathrm{~A}$ licence can therefore be granted if the location is situated in areas formally identified and opened under the OEA. In 2010, in a state-driven process not regulated by law, 15 areas along the Norwegian coast were identified as locations in the Ocean Wind Report. ${ }^{69}$ This was a separate process from the revision of the Barents Sea Plan, but they were carried out in close cooperation. Five areas identified in the report were situated along the coast of the Barents Sea, most of them were in shallow waters inside the baselines. Conflicts with 
other activities such as fisheries, shipping, petroleum and tourism were discussed in the Barents Sea Plan, building on the more extensive analysis in the Ocean Wind Report.

The main strategic overview and guidance for offshore wind, wave and tidal energy, and marine renewable energy in Scotland is contained in the SNMP. ${ }^{70}$ There is also a Sectoral Marine Plan (SMP) for offshore wind energy in Scottish territorial waters. Strategic guidance for offshore renewable energy is therefore provided jointly by the SNMP and the SMP. ${ }^{71}$

Offshore wind farms are capital intensive and need to connect to infrastructure. A top-down process has therefore emerged in both Norway and Scotland. In Norway, the selection of potential sites took place in a separate process for the whole country, while, in Scotland, the SNMP was adopted after several rounds of location identification. The subsequent Barents Sea plan was based on locations proposed in the national Ocean Wind Report. The SNMP was based on the existing locations for offshore wind, in compliance with the requirement for predictability.

The question asked above is whether the LME plans undermine predictability for private stakeholders in the aquaculture and offshore wind sectors. The point of departure, that LME planning takes an ecosystem approach and thus promotes adaptability in management, could lead to the conclusion that predictability is weakened. However, as stated explicitly in the Barents Sea plan, the prevailing view is that by contributing to clarity in terms of frameworks, coordination and management priorities, LME planning actually promotes predictability in perspective of the management-policy. This is even more so as the practice as seen above, is to base LME plans on established plans for offshore wind in Norway and Scotland, and for established plans for aquaculture in Scotland. Finally, in a legal perspective, as strategic policy instruments, not imposing legally binding restrictions on private stakeholders, the LME plans cannot affect expectations of predictability.

\section{Marine Spatial Planning}

\subsection{Introduction}

Maritime or marine spatial planning, MSP, is a process that facilitates the effective coordination and allocation of human activities (licences) and environmental protection, leading to a document, map or similar, 'the spatial plan'. At its best, MSP avoids, reconciles and minimises conflicts of interest. Plans are shaped through a public process of "analysing and allocating the spatial and temporal distribution of human activities" in marine areas to achieve ecological, economic and social objectives. ${ }^{72}$ Spatial plans promote the value of adaptive management as they are altered in cyclical processes, taking changing conditions in the knowledge base, the environment and human impact into consideration.

A regime can have several layers of marine spatial plans, ranging from strategic to multisector to sector-based. Plans that are integrated and strategic are characteristic, and they are thus developed before more detailed planning of specific individual projects. When planning specific projects, the question of allocation of ocean space and reconciling of conflicting interests is in the past, and what remain to be decided are specific choices of project infrastructure, project design and the terms of the licence. Licensing is addressed in section 5 below. 
MSP in Norway and Scotland, both the process and the management objectives, must comply with obligations under EU and international law. The EU, but not the EEA, requires that a basic system for MSP be created for each coastal member state under the MSP directive. ${ }^{73}$ The EU Renewable Energy Directive ${ }^{74}$ which is also implemented under the EEA Agreement, requires member states to promote renewable energy through strategies and plans. The UK as a whole and its devolved administrations, including Scotland, have a commitment to achieving good environmental status under the Marine Strategy Framework Directive (MSFD) and Water Framework Directive (WFD), and the WFD is implemented under the EEA-Agreement. ${ }^{75}$ Besides instruments under these directives, MSP can be a tool, as the MSP directive "aim to contribute to the $\ldots$ preservation, protection and improvement of the environment, including resilience to climate change impacts". ${ }^{76}$ The MSP process must meet obligations under the Aarhus Convention and Directive 2001/42/EC on the assessment of the effects of certain plans and programmes on the environment (the SEA directive) with respect to impact assessment and public and stakeholder participation, both of which are implemented in Norway and Scotland. ${ }^{77}$ The OSPAR Commission is also developing appropriate measures in line with the ecosystem approach to facilitate marine spatial planning in the OSPAR maritime area, including region-specific, tailor-made approaches. ${ }^{78}$

One question here is how predictability can be ensured for existing activity in a situation where a zoning change is implemented, for example a change from 'all rights reserved' to third party access. As the pressure on ocean space increases, the issue of rational use of marine space by means of multi-use and densification, combining activities relating to, for example, renewable energy, fisheries, extraction industries, aquaculture, transport and related infrastructure, becomes more pressing. Moreover, rationale use could decrease the pressure on ocean ecology and ocean space, thereby ensuring ecosystem and biodiversity conservation and addressing other environmental concerns. ${ }^{79}$ Correspondingly, private operators may rely on third-party access ${ }^{80}$ multi-use - such as integrated multi-trophic aquaculture $-{ }^{81}$ or similar in order to make their business profitable. Whether multi-use is feasible, could depend on the project; in Norway, the question of multi-use, for example combining wind farms with fisheries, versus fishery protection zones around a wind farm, is left open in the updated management plan for the Barents Sea. It is left to be addressed at later planning stages. ${ }^{82}$ When consistent with policies and the objectives of the SNMP, there is general policy support for co-existence within the Scottish marine area. ${ }^{83}$ A corresponding policy is pursued in Norway in land use planning, and there are also traces of it in recent policy documents relating to marine management. ${ }^{84}$

Marine spatial plans can serve as guidance documents for management or be legally binding on the future use of marine areas for specific single purposes or multi-use. Legally binding plans usually mean that no new licences can be granted, unless they are in accordance with the zoning plan. For established industries in the area, a new or revised MSP could entail unforeseen changes, so how is predictability ensured for existing activity? A legally binding plan will usually have no implications for existing use, meaning that such use can continue as before. These general reflections lead to the question; How does MSP facilitate adaptability, while at the same time ensuring predictability in the Norwegian and Scottish aquaculture and offshore wind sectors? A closer look the MSP regimes in the sectors may provide some answers.

\subsection{Aquaculture and offshore wind}

The aquaculture management system in Norway has developed since the 1980s. Its main elements are the protection of wild salmon rivers, a new system of 'aquaculture production zones', regional 
and municipal spatial plans, and licences. ${ }^{85}$ As the sector became larger and its impact more evident, temporary, and later permanent, fish farming restriction zones were established to protect wild salmon. A proposal setting out which rivers and fjords with wild salmon should have special protection, and where no further fish farming would be established, was presented to the Norwegian parliament in $2006-2007 .{ }^{86}$ In the process of prioritising and selecting rivers, pragmatic concerns relating to areas where aquaculture already existed were taken into consideration, thus ensuring foreseeability for private interests and rights. ${ }^{87}$ However, where aquaculture facilities were located in what became a protected salmon fjord, more stringent requirements were introduced for production growth and the control of salmon lice and other diseases, and also a duty to move facilities. $^{88}$

In 2015 a strategy for production growth in the sector was presented by the Government. ${ }^{89}$ As a result, in 2017, the coast was divided into 13 'aquaculture production zones' ${ }^{90}$ delimited in order to reduce the spread of sea lice and diseases. ${ }^{11}$ All aquaculture facilities are now assigned to a production zone to control future development based on the criteria: production growth, standstill or reduction (a traffic light system).$^{92}$ The potential consequences for production volumes of sea lice pressure mean that different operators in a production zone are dependent on each other's contribution to the sea lice problem. The legality of the proposed regulation was questioned, ${ }^{93}$ as well as the consequences for predictability. This lead to changes in the system, making it more flexible for the operators. ${ }^{94}$

Regional and municipal planning in Norway is regulated by the Planning and Building Act (PBA). ${ }^{95}$ The County Councils and the Municipal Councils have competence under the PBA to adopt marine spatial plans landward of the baselines and, since 2008, one nautical mile out to sea. ${ }^{96}$ Regional and local planning is steered by the Government which defines national expectations for four years at a time. ${ }^{97}$ These expectations function as guidelines for marine spatial plans. As strategic policy guidelines they have no direct impact on private stakeholders. In the guidelines, the Government now expects that the use of already allocated areas will be optimised, and that enough area is allocated for the fisheries and aquaculture industry while also taking account of environmental concerns and other social interests. ${ }^{98}$

Norway's 19 counties can adopt regional thematic plans, but this opportunity has not been utilised much for sea areas until recently. Southern Hordaland and Western Hardanger on the west coast of Norway is one of the largest aquaculture production regions in the world, and it is experiencing particular challenges with sea lice. In 2008, a temporary prohibition was introduced on issuing more aquaculture permits in defined parts of the region. ${ }^{99}$ A pioneer 'Regional Coastal Plan' with thematic maps and zoning has been developed. ${ }^{100}$ The counties designed the plan to ensure access to production areas with a potential for expansion where conflicts with other interests are low. In addition, multi-use zoning has been implemented in new areas to facilitate the use of new technology, both for sea-based aquaculture and for closed facilities closer to shore. ${ }^{101}$ For coastal zones with high pressure, more use of this regional planning instrument can be expected. For private stakeholders, the regional plans have no formal consequences, since the plans are not legally binding on subsequent municipal land use planning, nor on the issuing of licences by sector authorities. $^{102}$

Municipal land use planning in Norway facilitates coordination between the administrative branches of central government and regional and municipal bodies, and municipally approved plans 
now have directly binding effect on decisions made under the Pollution Control Act and the Aquaculture Act. ${ }^{103}$ The state and county can have a strong interest in development, and affected authorities can 'object' to a municipal plan e.g. contradicting a regional plan, in which case the final decision rests with the ministry. ${ }^{104}$ This instrument is intended to enforce the guidelines in the regional plans, thus making regional plans important for the future allocation of ocean space in municipal marine spatial plans.

MSP in the municipalities is particularly suitable for mapping and balancing private and public interests in sea use, while the overall ecological impact on the coastal ecosystem is given less weight. ${ }^{105}$ The municipal master plan determines future land use, and it is binding on new projects and the expansion of existing projects. ${ }^{106}$ The plan does not form a legal basis for expropriation, for example of existing facilities. Existing industry is thus protected in this regard.

The planning and regulation of aquaculture in Scotland is a hotly debated political issue. ${ }^{107} \mathrm{~A}$ complex management and regulatory regime has developed since its introduction to Scotland in the 1970s. It contributes to sustainable economic growth in rural and coastal communities, especially in the Highlands and Islands, and the SNMP recognises that it has the potential to contribute to further community cohesion. ${ }^{108}$ MSP regional guidance is also available for aquaculture, for example the Shetland Islands' Marine Spatial Plan, which notes that all applications for aquaculture development will be considered in accordance with the Council's Aquaculture Policy, which was adopted as part of the supplementary guidance relating to the Local Development Plan. ${ }^{109}$ The other relevant local MSPs authorities are Highland, Orkney, the Western Isles, and Argyll and Bute councils and with Marine Scotland they provide detailed local guidance: Aquaculture Development Framework Plans. Terrestrial development plans also include locational guidance for new fish farm development including locations for new fish farm development. ${ }^{110}$ Scottish Government is encouraging identification of large offshore sites to both increase in the value of the industry and reduce environmental impacts in sensitive inshore locations. ${ }^{111}$ As in Norway, bringing sea lice under control is recognised as a substantial challenge. ${ }^{112}$ Farm Management Areas (FMAs) and statutory farm management agreements aim to promote biosecurity and disease and parasite control as part of wider control and enforcement regime. ${ }^{113}$

Aquaculture planning in Norway and in Scotland is part of the land use planning system - extended out to sea - and at the same time part of a developing offshore planning system in Scotland. In Norway, the state, the county authorities and the municipalities contribute to MSP for aquaculture, but only municipal plans impose legal restrictions on future activity. The aquaculture regimes appear to be working well in both jurisdictions as regards predictability, even though it can be challenging to relate to the Scottish system in this phase of implementing the SNMP in the aquaculture sector. Compared to municipal plans, the ecosystem approach and value of adaptability is at the forefront of the development of regional coastal planning in Norway, and through protective measures for wild salmon and the introduction of production zones. In Scotland, the ecosystem approach is evident in the SNMP, but it is not specifically required by the Scottish land use planning system. Co-existence and synergies in relation to aquaculture are not specifically fostered and developed here. It is also recognised that the specific and particular challenge for the aquaculture industry of sea lice cannot be addressed by planning principles alone, but also by pragmatic and practical environmental health laws and policies working in tandem with planning.

The Norwegian Ocean Energy Act (OEA) requires a marine spatial plan for the 'opening of areas', with a view to the granting of license, and applications outside such areas can be rejected. ${ }^{114}$ As described, the initial policy process for the allocation of offshore wind farms in Norway took place 
in connection with the Ocean Wind Report and it was replicated in the updated Barents Sea plan. The reports suggested that fifteen areas fell under OEA section 2-2 and were required to carry out strategic impact assessments (SEA) under the formal process of 'opening of areas'. ${ }^{115}$ The 2012 SEA report states that business, social and environmental interests in and around the investigated areas, and the technical and economic suitability of the areas, are to be assessed. ${ }^{116}$ The influence of previous planning is evident in the methodological approach, as the assessment is based on 'existing knowledge', but also on the LME plans, such as the Barents Sea plan. ${ }^{117}$ As a governmentrun SEA process carried out before anything is known about potential applicants, it is underlined that the impact assessments are carried out at an overall level, and with the goal of generating sufficient relevant knowledge for a decision to be made on whether or not the area should be opened. ${ }^{118}$ The 2012 SEA divided the areas into areas for immediate opening, areas rejected due to the existing technological situation, and areas for consideration at a later stage. ${ }^{119}$ The formal decision on whether to open areas has not yet been taken, ${ }^{120}$ but a revised evaluation concluded in 2017 that the 2012 SEA is still valid as the basis for a decision on opening. ${ }^{121}$

The current Scottish Government position is to build a globally competitive offshore wind and marine renewables industry. ${ }^{122}$ Scotland's marine area are estimated to have $25 \%$ of Europe's offshore wind and tidal resources. Scotland's Wind and Marine Renewable Energy strategy is set out in the SNMP Chapter 11. Objectives include sustainable development of offshore wind in the most suitable locations; ${ }^{123}$ maximising economic benefits from offshore wind, wave and tidal energy developments by securing a competitive local supply chain in Scotland; ${ }^{124}$ and to contribute to achieving the decarbonisation target. ${ }^{125}$ Planning policy for offshore renewable energy is contained in the SNMP. The policy consists of the maps and plans known as the Adopted Plan Options. ${ }^{126}$ These actually predated the SNMP and are the strategic development zones in which commercialscale projects should be sited following further detailed zone planning and Sustainability Appraisal. ${ }^{127}$ These Plan Options have been identified by a multi-stage process involving a scientific scoping exercise to identify resource and constraint areas. Regional Locational Guidance, detailing relevant information and an early-stage consultation are then used to refine these 'Areas of Search' into Draft Plan Options, which are subject to a Sustainability Appraisal (including SEA, Habitats Regulation Appraisal and socio-economic assessment) plus statutory consultation prior to adoption. ${ }^{128}$ It is the outcome of these detailed investigations that are included in the SNMP.

The SNMP notes that key marine sectors can be affected by marine renewable energy development. Physical competition for space, navigational restrictions and the impact of physical structures in the sea may affect sectors such as fisheries and aquaculture, marine recreation and tourism, shipping and defence, especially where a planned development spatially interacts with existing uses. ${ }^{129} \mathrm{~A}$ new Scottish Offshore Renewables Research Framework with a supporting research strategy is being developed. It is anticipated that it will provide a mechanism for new knowledge to feed into updates of the Sectoral Marine Plans and support Marine Scotland's risk-based licensing and consenting approach. ${ }^{130}$ The SNMP expects a strategic approach to mitigating potential impacts and cumulative impacts on the marine environment to be an integral part of marine planning and decision making, while issues arising in the coastal interface should align marine and terrestrial interests. ${ }^{131}$ However, the processes are still regarded as insufficiently mature at the time of writing to be able to verify these claims. Overall, the legal requirements in Scotland have focused on the duty imposed on Scottish Ministers to create the SNMP. Once adopted, the SMNP has to be taken into account in all marine environment decisions by public bodies. There has been no research on how the SNMP has been used in such decisions or any challenge about how it has been used. 
From this overview, it follows that MSP for offshore wind farms in both jurisdictions follows the offshore planning system and a strict planning hierarchy from strategies to licences. Predictability is furthered through plans, and advance licences. MSP plans for offshore wind farms are developed in close cooperation with the strategic planning of large marine ecosystems, and they promote the ecosystem approach and value of adaptability. In Norway, the evaluation of whether the 2012 SEA is sufficiently up-to-date to form the basis for the opening of areas for offshore wind today, illustrates the adaptive approach to knowledge sampling. MSP promotes predictability, but also adaptability and flexibility, and it is open to new or more relevant and specific knowledge.

\section{Licences}

\subsection{Introduction}

A licence to operate an aquaculture or offshore wind farm is the final step that gives the 'go ahead' for a project. This process can consist of several licences from different administrative bodies and, in some cases, a detailed plan, setting out the terms. The value of predictability requires that the economic value of the licence is given due protection, while, at the same time, adaptability considerations could imply a need for changes in the terms or revocation of the licence.

The core function of a licence is to regulate the rights and duties of the licensee, such as the right to use a particular marine space, exclusively or together with third parties. As third parties, such as marine transport, can be affected by the terms of the licence, predictability for such parties is also important, but will not be discussed here. The process of formulating the specific licence terms should be clear and accessible from the outset. ${ }^{132}$

Rule of law values, such as protection against retrospective laws, are fundamental legal values in the legal systems of both Norway and Scotland. The protection of property rights against retroactive effect means that, if a plan, in accordance with the law, requires a person to 'surrender their property' for the public use, they shall receive full compensation. ${ }^{133}$ These rule of law values have implications for legislation on revoking or altering existing licences. It is more difficult to cope with changes if licences can hardly be reviewed or revoked at all than if such opportunities exist, albeit regulated. Thus, the legal implications of a permit or licence 'matter from a resilience and flexibility point of view'. ${ }^{134}$ Due protection should be given to established rights, even if they are not 'surrendered', but subject to encroachments.

Predictability in the context of licences cannot be discussed in isolation. In a management hierarchy, from marine policy and strategic plans to marine spatial plans and detailed plans, expectations are created pursuant to the law. This could, for example, be an expectation of starting an aquaculture enterprise at a specific site. The link between planning and licensing in the specific systems of Norway and Scotland is thus relevant to the value of predictability.

\subsection{Aquaculture and offshore wind}

In Norway, aquaculture activity requires registration as the holder of an aquaculture licence. ${ }^{135}$ It is regulated by several laws, including the 2005 Aquaculture Act, the 2003 Food Safety Act and the 2009 Animal Welfare Act, ${ }^{136}$ which govern the allocation of licenses, the geographical areas where production is to take place and the maximum biomass permitted at the site. The process includes a biological risk assessment, but seldom an EIA. The licence applies to a particular site. The Aquaculture Act section 5 sets out the legal basis for provisions on the contents of aquaculture 
permits, including a limitation of the duration of the permit. Still, normally the licence is not timelimited. ${ }^{137}$ It is stated in the Act that a licence can only be granted if it is environmentally sound. ${ }^{138}$ section 9 regulates when a licence can be revoked by the authorities or its terms altered, for example if this is "necessary for the sake of the environment" or if "the essential assumptions underlying the licence have been changed". These rules open for adaptation to a situation where negative environmental impacts arise, while at the same time protecting values of predictability by the terms being enshrined in law, regulations or a licence. By using legal terms with broad room for interpretation, such as 'necessary for the sake of the environment', it could be argued that predictability is low as regards when a licence can be revoked. However, the many detailed regulations framing the industry, substantially narrow the leeway for interpretation.

The Parliament determines the number of licences, which are awarded in allocation rounds by the ministry. Sea lice pressure is decisive for production growth in the 'production areas', (growth of up to $6 \%$ ), standstill or reduction, and it could be argued that establishing production areas increases predictability for fish farmers in relation to when and whether production can be increased. ${ }^{139}$ The system is still criticised for over-simplification as regards ecosystem impacts, since only sea lice pressure is used as an indicator. ${ }^{140}$ In 2015 started a process of awarding licences to innovative research and development-projects, ${ }^{141}$ and such research and development licences can be converted into ordinary licences. ${ }^{142}$ The award criteria are very open in order to facilitate innovation, but this does reduces predictability about what will be decisive. ${ }^{143}$

When the county authority evaluates an aquaculture license application, it is forwarded to the relevant municipality. Applications that are in conflict with the marine spatial plan (master plan) at the municipal level can be rejected. ${ }^{144}$ Where no municipal master plan exists, the Planning and Building Act is not relevant, and sectoral legislation is decisive. ${ }^{145}$ The lack of a marine spatial plan at the municipal level hinders the establishment of a link from spatial plan to licence, and the complementary holistic and adaptive approach. In order to compensate for the lack of a spatial plan, management principles stemming from the Nature Diversity Act will be applied in the licensing process, ${ }^{146}$ which will have to adopt a broader perspective and look at issues such as the geographical scope of the land-sea interface, knowledge and mapping of conflicting interests and uses. ${ }^{147}$ That said, the lack of a municipal master plan for the sea area could itself indicate that the area is under less pressure from existing development and use.

In Scotland, aquaculture activity requires a lease from The Crown Estate, plus a variety of licenses and environmental permits depending on size and location. ${ }^{148}$ Marine Scotland's Licensing Operations Team (MS-LOT) issues licences for construction, alteration or improvement of a fish farm, ${ }^{149}$ as well as for seal management. ${ }^{150}$ Source discharge authorisations are obtained from the Scottish Environmental Protection Agency (SEPA) for biomass of fish and the range and quality of chemicals released into the environment. ${ }^{151}$ The cumulative effect may also require a European Protected Species Licence. ${ }^{152}$ Fish health is regulated by the Aquaculture and Fisheries (Scotland) Act 2013 and provide measures for prevention, control and reduction of parasites. ${ }^{153}$

From 2007, aquaculture has been incorporated into the land use planning system. This recognised that it was inappropriate for The Crown Estate to issue both leases and licences for fish farms. ${ }^{154}$ In terms of rule of law values, the original regime fell short of standards of transparency, participation and access to justice. Thus, an informal arrangement was adopted whereby the advice of planning authorities on licensing decisions was always adopted by The Crown Estate until the law was changed, initially as part of the legal regime which implemented the EU Water Framework 
Directive. ${ }^{155}$ Although this was considered a good workaround solution at the time, aquaculture is now an outlier to what is intended to be a holistic system of marine management when MSP was introduced. Marine aquaculture was in fact, very much at the forefront of the thinking around and development of MSP in Scotland. ${ }^{156}$ However, it remains part of the land use planning system rather than being incorporated into the now established marine planning regime, although a detailed policy context exists to support the current arrangements. ${ }^{157}$

Aquaculture development out to $3 \mathrm{~nm}$ requires planning permission. ${ }^{158}$ In making their decisions, the planning authority will utilise both strategic and local policy guidance and work closely with Marine Scotland. ${ }^{159}$ Aquaculture applications must comply with all the planning permission requirements, including EIA. ${ }^{160}$ There is a statutory expectation that decisions will have regard to the development plan, ${ }^{161}$ but also adopt an ecosystem approach. ${ }^{162}$ Approvals will have planning conditions, which are subject to the planning enforcement regime and further detailed information must often be provided before implementation. Most planning permissions for aquaculture development are now not time limited, making them permanent, whereas prior to 2007 only temporary consent was granted which required to renewed after the period set for the temporary consent had expired. ${ }^{163}$ Decisions by the planning authority can be appealed to Scottish Ministers. ${ }^{164}$

Planning is only a part of the regulatory regime for aquaculture in Scotland, as indicated above. It is SEPA who have the power to suspend, revoke a licence if it is in noncompliance with licence conditions. ${ }^{165}$ Overall, although it is a complex system which has been amended and augmented, since the major changes in 2007 , it is one that has delivered predictability and adaptability. As the industry matures, there is increasing concern about the reality of its impact on the environment and in particular on wild fish stocks. There is also a desire by the industry to diversify and to expand. This is supported in principle by Scottish government, however, for example, a Scottish Parliamentary Committee on salmon farming in Scotland has recommended "if the industry is to grow... it (is)... essential that (the industry) addresses and identifies solutions to the environmental and fish health challenges it faces as a priority". ${ }^{166}$ It goes on to state that the status quo in terms of regulation and enforcement is not acceptable. ${ }^{167}$ It will be interesting to see how the regulatory framework for aquaculture in Scotland will develop and how predictability and adaptability are addressed in the future.

In Norway, a licence is required for wind farms with associated infrastructure under the Ocean Energy Act. ${ }^{168}$ Licences for projects like wind farms can be granted if they are situated in areas that have been formally 'opened' for this activity under the MSP. ${ }^{169}$ Because wind farms, even as floating structures, are anchored to the seabed, the licences relate to a particular site on the seabed. When granted a licence, the licensee may be required to pay an area fee to the state. ${ }^{170}$ The Act provides a legal basis for regulating or setting terms in relation to the rights and duties of the licensee, for instance regarding measures to avoid or limit environmental impacts and negative impacts on natural diversity, the cultural heritage and other land use. ${ }^{171}$ Changes to the terms may be made upon application from the licensee. Section 10-7 regulates in detail when a licence can be revoked by the authorities. These rules promote predictability by being clearly worded. They still open for adaptation to a situation where negative environmental impacts arise; if the licensee violates the terms of the licence, and the violation is "significant", the licence may be revoked. The question of what is 'significant' could create unpredictability for the licensee, at the same time as it could be in the licensee's interest not to have rigid standards. 
Licences are granted for a limited period of up to 30 years, but can be extended by application. ${ }^{172}$ It is not expressly stated, but this must open for new terms by the end of the licence period even if the ownership is in the same hands. Section 10-8 provides an additional legal basis for altering the terms of a licence in "special cases" in order to protect public interests, giving due consideration to the costs that a change will cause to the licensee and the benefits and disadvantages the change will result in.

Offshore wind energy projects in Scottish waters fall under the Scottish government's competence, but are subject to a mixture of reserved and devolved laws. ${ }^{173}$ Blocks of U.K waters have been identified by The Crown Estate, as owner of the sea bed, for offshore energy development. There have been three rounds to date and all applications and approvals have been located in these areas, which have been subject to Strategic Environmental Assessment. ${ }^{174}$ The Crown Estate has now been devolved and Crown Estate Scotland commenced consultation on a further leasing round in 2017-18. ${ }^{175}$

Any proposal to construct, extend or operate a generating station in the Scottish territorial waters $(0-12 \mathrm{~nm})$ and Offshore region $(12-200 \mathrm{~nm})$ from the with a generating capacity in excess of 50 megawatts, requires consent under section 36 of the Electricity Act. ${ }^{176}$ There is a duty on those formulating such proposals to have regard to the desirability of preserving natural beauty, of conserving flora, fauna and geological or physiographical features of special interest and of protecting sites, buildings and objects of architectural, historic or archaeological interest and there is a requirement to reasonably mitigate the effect of the proposals have on these features. ${ }^{177}$ Licence holders must also avoid, as far as possible, causing injury to fisheries or to the stock of fish in any waters. ${ }^{178}$ Scottish Ministers may not grant consent in relation to any particular offshore generating activities if they consider that interferences with the use of recognised sea lanes essential for international navigation is likely to be caused. ${ }^{179}$

Individual projects will only be considered in areas that have previously been identified in leasing rounds. As well as consent under the Electricity Act a marine licence is now required under the Marine Acts, also issued by Scottish Ministers, ${ }^{180}$ and management of the projects must comply with the conditions attached to the licences. As with aquaculture, Marine Scotland (MS-LOT) is the regulator responsible for assessment and determination of the marine licences and the consent to generate electricity. ${ }^{181}$ Offshore energy projects also require leases from The Crown Estate to carry out work on the sea bed. Decisions must be based on an ecosystem approach and have regard to the National Marine Plan. ${ }^{182}$ Scottish ministers must also exercise their functions in compliance with the requirements of the Climate Change (Scotland) Act 2009. ${ }^{183}$ Most offshore wind farms will require an EIA. ${ }^{184}$ There are extensive consultation requirements in relation to the natural heritage, environmental protection and neighbouring planning authorities. ${ }^{185}$

Decisions are based on striking a balance between policy and other considerations. Reasons must be provided for a refusal and an approval will come with a list of conditions. The decision is final, subject to the right of any aggrieved person to apply to the Court of Session for a judicial review. ${ }^{186}$ All approvals will include a condition relating to decommissioning of the windfarm at the end of the license period, normally 25 years after the final commissioning of the development. MS Lot on behalf of Scottish Ministers may vary, suspend or revoke a licence if it appears that there has been 
a breach of any of the licence provisions; that false information had been supplied or new information effects the decision on the licence. ${ }^{187} \mathrm{~A}$ compliance notice can be issued to address issues of non compliance and remediation. ${ }^{188}$

There is a certain amount of predictability in Scotland due to the leasing rounds and the SEA process. The lease is the first step and must be obtained from The Crown Estate. This however, is broad brush and very much a first step and merely establishes the principle that development will be acceptable. Before any work can take place the detail must be approved from the government regulator in the form of detailed licences and consents. The leasing procedure provides clarity at least on where offshore energy projects will not be located in the foreseeable future. In terms of the detail there is a complex legislative and policy framework which has emerged almost incrementally to deal with an increasing array of technical and environmental issues including cumulative impact and links with the onshore facilities. Conditions attached to the consents and licences should facilitate adaptability, many require detailed information to be provided and have ongoing monitoring and assessment requirements.

As noted above, licences can be granted for projects like wind farms in Norway if the farm is situated in an area that has been formally 'opened' for this activity under the MSP. Applications outside opened areas can be rejected by administrative decision without further investigation. The intentions behind the MSP are thwarted if subsequent projects do not largely follow the MSP. The use of dispensations from the plans and related provisions can undermine the holistic approach. ${ }^{189}$ Thus, the vertical management hierarchy is strict, linking strategic planning with downstream project licences, promoting a holistic approach and predictability. The system is modelled on the Petroleum Act, ${ }^{190}$ but, as opposed to the extraction of petroleum, wind energy turbines have greater flexibility with respect to location. It is an open question whether this strict system will lead to a lack of flexibility, for instance where it is necessary to re-evaluate because of the development of new technology and energy infrastructure. The time lag between the opening process and the granting of a licence will be relevant, as will the possibility of opening other areas than the 15 already evaluated. The size and position of the opened areas are also relevant in relation to flexibility. The licensing system in Scotland is at the time of writing delivering offshore wind projects to fruition, but it has been a prolonged process and other factors over and above MSP have also influenced the finalisation of projects. ${ }^{191}$ The unique role of The Crown Estate establishing the areas in the first instance where a lease can be obtained remains pivotal.

\section{Some final reflections}

Reviewing marine governance systems for offshore wind farms and aquaculture facilities in Norway and Scotland gives rise to interesting reflections and some conclusions can be drawn.

In both jurisdictions, the system of marine governance is made up of a complex patchwork of competences between national, regional and local authorities, the land-sea interface and licences, and, in both jurisdictions, in addition to horizontal structures, a vertical hierarchy has developed that provides national strategic guidance for the marine environment as a whole, as well as for aquaculture and offshore wind developments. For these complex systems, an analysis based on a legal values perspective enables wider lessons to be learnt. The distinct difference between the drivers in the development of the management of the aquaculture sector and the offshore wind sector illustrates that 'one-size-fits-all' policies are not effective;' ${ }^{192}$ the sectors have developed within quite different policy frameworks. Despite the sectors' different frameworks, it is an 
interesting finding that both Norway and Scotland have taken parallel policy approaches to aquaculture and offshore energy, respectively.

Of course, nuances are lost in a brief analysis of this kind. However, studying core elements of the systems, illustrated by comparing structures and rules fulfilling the same functions in the two sectors, illuminates that values of predictability are not only reflected in specific rules, but also in the construction of the overall management system. The constant evolution of the management systems in both countries, which is particularly evident in the mature aquaculture sector, reflects the ability to adapt management to emerging management challenges. Changes in the system are still slowly evolving and are grounded in democratically adopted laws, promoting predictability in the broader sense for marine businesses. The balance between flexibility and adaptability is thus illustrated at system level. The comparative functional approach, taken with a view to identifying the system's ability to protect values of predictability and adaptability, could be a fruitful model for further studies of the Arctic.

\footnotetext{
${ }^{1}$ Functional comparative method focuses not on rules but on their effects, see Michaels, Ralf, The Functional Method of Comparative Law. The Oxford Handbook of Comparative Law, Mathias Reimann \& Reinhard Zimmermann, eds., Oxford University Press, Duke Law School Legal Studies Paper No. 87 https: / / ssrn.com/abstract $=839826$, p. 4. All web site listed in this article are last visited 9 Jan. 2018

${ }^{2}$ For general perspectives on the rule of law in governance of complex socio-ecological changes, see J. Ebbesson, The rule of law in governance of complex socio-ecological changes, Global Environmental Change, 20 (2010) 3, 414422 https://doi.org/10.1016/j.gloenvcha.2009.10.009.

${ }^{3}$ Temperate Northern Atlantic see M.D. Spalding, H.E. Fox, G.R. Allen, N. Davidson et al., Marine Ecoregions of the World: A Bioregionalization of Coastal and Shelf Areas, BioScience, 57 (2007) 7, 573-583,

https://doi.org/10.1641/B570707. Ecoregions are defined as areas of "relatively homogeneous species composition, clearly distinct from adjacent systems", p. 575.

${ }^{4}$ https://www.beatricewind.com/.

${ }_{5}^{5}$ Norway produced 1233619 tons salmon in 2016, Statistisk sentralbyrå, Akvakultur. https://www.ssb.no/jordskog-jakt-og-fiskeri/statistikker/fiskeoppdrett/aar. Scotland produced 162817 tons in 2016, Scottish Government, Scientific Publications. http://www.gov.scot/Topics/marine/Publications/stats. Faroe Islands produce approx. 6090.000 tons salmon per year, while Island has had challenges, but from 2009 regular salmon production has taken place, and has the potential to grow to the same volume, A. Berge, ilaks.no, Ønsker kraftig vekst for lakseoppdrett på Island, published 22.07.2016. https://sysla.no/fisk/onsker-kraftig-vekst-for-lakseoppdrett-pa-island/. Aquaculture is a relatively new industry for Russia, developing particularly from 2014 as a response to Crimea-related sanctions, see https://www.seafoodsource.com/news/aquaculture/despite-obstacles-russia-s-aquaculture-sets-sight-on-triplingproduction-by-2030. Finland produce salmon trout in the Baltic, for data from 2017 see

https://stat.luke.fi/en/aquaculture-2017 en, and opened the country's first commercial offshore wind site in 2017 in the Gulf of Bothnia, https://www.windpoweroffshore.com/article/1443438/offshore-tahkoluoto-project-officiallyopened.

${ }^{6}$ S.E. Schütz, Marine Spatial Planning - Prospects for the Arctic, Arctic Review, 9 (2018), 44-66, https://doi.org/10.23865/arctic.v9.899.

7 The new marine management law in Scotland is implemented by way of statutes: Marine and Coastal Access Act 2009 and Marine (Scotland) Act 2010 and is superimposed upon Scots law relevant for land ownership and dispute resolution.

${ }^{8}$ Both Norway and Scotland have growth in aquaculture production as a political goal, for Norway see Meld. St.16 (2014-2015) Forutsigbar og miljømessig bærekraftig vekst i norsk lakse-og ørretoppdrett, and for Scotland, see Aquaculture growth to 2013, A strategic plan for farming Scotland's seas. The United Nations Food and Agriculture Organisation estimates aquaculture will provide for close to two thirds of global food consumption by 2030 as catches of wild capture fisheries level off and demand increases. Fish to 2030: prospects for Fisheries and Aquaculture. World Bank 2013. Agriculture and environmental services discussion paper; no. 3 Washington DC; World Bank Group.
} 
${ }^{9}$ For the Norwegian sector, see Meld. St. 10 (2010-2011) Oppdatering av forvaltningsplanen for det marine miljø i Barentshavet og havområdene utenfor Lofoten p. 73 , and at p. 75 it is estimated a theoretical potential for off shore wind to 14000 TWh /year. Scotland's marine area is estimated to have $25 \%$ of Europe's offshore wind resource.

${ }^{10}$ UN General Assembly, Transforming our world : the 2030 Agenda for Sustainable Development, 21 October 2015.

${ }^{11}$ Rule of law enhances Certainty, Predictability, and Security, Tamanaha, Brian Z., A Concise Guide to the Rule of Law. Florence workshop on the rule of law, Neil Walker, Gianluigi Palombella, eds., Hart Publishing Company, 2007; St. John's Legal Studies Research Paper No. 07-0082. https://ssrn.com/abstract=1012051, p. 8.

12 Ibid p. 8.

13 Ibid p. 3.

${ }^{14}$ Convention for the Protection of Human Rights and Fundamental Freedoms, 4 November 1950, ETS No.005, in force from 3 September 1953.

${ }_{15}$ Protocol to the Convention for the Protection of Human Rights and Fundamental Freedoms, 20 March 1952, ETS No.009, in force from 18 May 1954.

${ }^{16}$ Grand Chamber, 29. mars 2010 Brosset-Triboulet and Others v. France, sec. 65, EMD-2002-34078-2 sec. 65.

17 Ibid sec. 66.

18 Ibid.

${ }^{19}$ United Kingdom Government has devolved powers to the Northern Ireland Assembly, the Scottish Government and Welsh Assembly Government. For Scotland the transfer of powers has been an ongoing process since 1998: Scotland Act 1998 and Scotland Act 2016.

20 The Norwegian constitution; Kongeriket Norges Grunnlov 17.05.1814, sec. 113.

${ }^{21}$ Ibid. sec. 97.

${ }^{22}$ Grand Chamber, 29. mars 2010 Brosset-Triboulet and Others v. France, sec. 66, EMD-2002-34078-2.

23 See further sec. 3 to 5 .

${ }^{24}$ F. M Platjouw «Environmental Law and the Ecosystem Approach", Routledge 2016, p. 19, recognicing that the concept is lacking a formal, universally agreed definition, p. 20.

${ }^{25}$ Ibid p. 23.

${ }^{26}$ Malawi principles nr. 9.

${ }^{27}$ F. M Platjouw «Environmental Law and the Ecosystem Approach”, Routledge 2016 p. 131.

${ }^{28}$ See further on licences in sec. 5 .

${ }^{29} \mathrm{~J}$. Ebbesson, The rule of law in governance of complex socio-ecological changes, Global Environmental Change, 20 (2010) 3, 414-422, https://doi.org/10.1016/i.gloenvcha.2009.10.009, p. 418.

${ }^{30}$ Ibid.

${ }^{31}$ See further on marine spatial plans in sec. 4.

32 See further on strategic planning in sec. 3.

${ }^{33}$ C. Ehler, F. Douvere, Marine Spatial Planning: a step-by-step approach toward ecosystem-based management, IOC Manual and Guides No. 53, ICAM Dossier No. 6. UNESCO, Intergovernmental Oceanographic Commission and Man and the Biosphere Programme (2009), http://unesdoc.unesco.org/images/0018/001865/186559e.pdf. Its basic concept derives from the 1992 Convention on Biological Diversity (CBD), where Norway and Scotland are contracting parties, defined as "a strategy for the integrated management of land, water and living resources" that will help to reach balancing conservation, sustainable use and the fair and equitable sharing of genetic resources.

Decentralized systems could be used, leading to greater efficiency, effectiveness and equity, and it is argued that the closer management is to the ecosystem "the greater the responsibility, ownership and accountability, participation, and use of local knowledge", see COP 5 Decision V/6 B 6. At the same time it is there stated that the ecosystem approach "may require new arrangements or ways of organization in for institutions involved in decision-making". The concept itself has thus no precise requirements for the structuring or organizing of marine governance.

${ }^{34}$ Strategic planning of LMEs is not, as yet, a fixed concept in international theory.

35 The 1992 Convention for the Protection of the Marine Environment of the North-East Atlantic (OSPAR), placing a duty on the members to impose measures not only in order to safeguard human health and to conserve marine ecosystems, but also when practicable, to restore adversely affected areas while applying the precautionary principle, polluter pays principle, best available technology and best environmental practice.

36 As an EEA member, Norway has implemented the environmental quality norms under the Directive 2000/60/EC, Water Framework Directive, (WFD) but rejected the Directive 2008/56/EC, Marine Strategy Framework Directive, (MSFD) and the Directive 2014/89/EU, Maritime Spatial Planning Directive, (MSP) under the agreement, thus the management plans are not formally operationalising the directives. For the UK, and therefore Scotland, as a current EU member, the EU Natura 2000 regulations will be relevant, opposed to Norway, as the EEA-Agreement excludes nature protection from its scope. In the short term after BREXIT all EU regulations will be transferred into U.K law.

${ }^{37}$ M.J. Westgate, G.E. Likens, D.B. Lindenmayer, Adaptive management of biological systems: A review. Biological Conservation 158 (2013), 128-139 https://doi.org/10.1016/j.biocon.2012.08.016 and N.J.I. Rodriguez, A comparative analysis of holistic marine management regimes and ecosystem approach in marine spatial planning in developed countries, Ocean \& Coastal Management, 137 (2017), 185-197

https://doi.org/10.1016/j.ocecoaman.2016.12.023. 
38 The division of the norwegian marine planning regions are closely linked to the large marine ecoregions, see M.D. Spalding, H.E. Fox, G.R. Allen, N. Davidson et al., Marine Ecoregions of the World: A Bioregionalization of Coastal and Shelf Areas, BioScience, 57 (2007) 57 (7), 573-583, https://doi.org/10.1641/B570707, where Norway Exclusive Economic Zone (EEZ) belonging to the '25. North Sea', '22. Southern Norway' and '23. Northern Norway and Finnmark' pp. 577-578.

${ }^{39}$ St.meld. nr. 8 (2005-2006) Helhetlig forvaltning av det marine miljø i Barentshavet og havområdene utenfor Lofoten (forvaltningsplan) (Report No. 8 to the Parliament (2005-2006). Integrated Management of the Marine Environment of the Barents Sea and the Sea Areas off the Lofoten Islands), https://www.regjeringen.no/en/dokumenter/Report-No-8-to-the-Storting20052006/id456957/?q=Report\%20No.\%208\%20to\%20the\%20Storting. Later updated; Meld. St. 10 (2010-2011), Oppdatering av forvaltningsplanen for det marine miljo $i$ Barentshavet og havomradene utenfor Lofoten, (Report to the Parliament (white paper), First update of the Management Plan for the Barents Sea - Lofoten Area), https://www.regjeringen.no/en/dokumenter/meld.-st.-10-20102011/id635591/.

${ }^{40}$ In south west the delimitation is by the Norwegian Sea, in north it includes the fishery protection zone around the Svalbard archipelago to the Arctic Ocean, and in east by the Russian part of the Barents Sea, ibid. p. 17 and upheld in the First update of the Management Plan for the Barents Sea - Lofoten Area .

${ }^{41}$ Ibid.

42 Meld. St. 20 (2014-2015) Melding til Stortinget, Oppdatering av forvaltningsplanen for Barentshavet og havomradene utenfor Lofoten, (Report to the Parliament (white paper) Update of the integrated management plan for the Barents SeaLofoten area including an update of the delimitation of the marginal ice zone), https://www.regjeringen.no/en/dokumenter/meld.-st.-20-20142015/id2408321/ p. 5.

${ }^{43}$ Marine and Coastal Access Act 2009 and Marine (Scotland) Act 2010. These two Acts (together referred to as the Marine Acts) established a process for a new legislative and management framework for the marine environment. ${ }^{44}$ HM Government, UK Marine Policy Statement, March 2011.

${ }^{45}$ UK Marine Policy Statement, March 2011 p. 3 and Marine Policy Statement and draws on the UK Marine High Level Marine Objectives 2009. On the ecosystem approach see fn 6; "The management of human activities which ensures that collective pressure of human activities is kept within levels compatible with the achievement of good environmental status; that does not compromise the capacity of marine ecosystems to respond to human induced change and that enables the sustainable use of marine goods and services".

46 The basis for a new ecosystem-based management of the Norwegian sea and coastal areas was set out in Report no. 12 (2001-2002) to the Parliament, Protecting the Riches of the Seas . In Report No. 37 to the Parliament (20082009), Integrated Management of the Marine Environment of the Norwegian Sea, it is stated that since the introduction of the management plan for the Barents Sea-Lofoten area, "the development of an integrated, ecosystem based marine management regime has been further strengthened by the Nature Management Act

(Proposition No. 52 (2008-2009) to the Parliament) and the new Marine Resources Act, which entered into force on 1 January 2009”, p. 11. Still, these Acts does not regulate the management plans as such.

${ }^{47}$ Marine and Coastal Access Act 2009 and Marine (Scotland) Act 2010 s 15(1).

${ }^{48}$ Scotland's National Marine Plan, The Scottish Government, Edinburgh 2015, para 3.2.

${ }^{49}$ See M.D. Spalding, H.E. Fox, G.R. Allen, N. Davidson et al., Marine Ecoregions of the World: A

Bioregionalization of Coastal and Shelf Areas, BioScience, 57 (2007) 57 (7), 573-583,

https://doi.org/10.1641/B570707, where Scotland's EEZ falling under the '25. North Sea' and the '26. Celtic Sea', pp. 577-578.

${ }^{50}$ Schedule 1 Marine (Scotland) Act 2010

51 A network of marine protected areas, MPAs, has been planned separately from the marine offshore management plans, and will be given a more formalized legal protection status, NJI Rodriguez, A comparative analysis of holistic marine management regimes and ecosystem approach in marine spatial planning in developed countries, Ocean \& Coastal Management, 137 (2017), 185-197 https://doi.org/10.1016/i.ocecoaman.2016.12.023 sec. 4.1. Planned protected areas are an important premises in the management plans, see First update of the Management Plan for the Barents Sea - Lofoten Area, sec. 4.5.1.

${ }^{52} \mathrm{It}$ is required to be compatible with the UK Marine Policy Statement and existing marine plans across the UK, in particular where there is an interaction between England inshore and offshore marine plans and Northern Ireland Marine Plans under the Marine and Coastal Access Act 2009 and Marine (Northern Ireland) Act 2013.

${ }^{53}$ First update of the Management Plan for the Barents Sea - Lofoten Area , p. 5.

${ }^{54}$ For details, see sec 4.2 and 5.2 .

${ }^{55}$ For details, see sec. 4.2 .

${ }^{56}$ Scottish Executive Development Department, 'The Extension of Planning Controls to Marine Fish Farming' (Consultation paper, Scottish Executive 2000).

${ }^{57}$ For the future this may change, as new 'innovative research and development-permits' are issued, where the open ocean is the potential area for the industry, see Redaksjonen, Salmar vil utvikle enda større havmerd - har kjøpt seg inn i MariCulture AS, published 13.04.2018, https://www.kyst.no/article/salmar-vil-utvikle-enda-stoerre-havmerd/ and sec. 5.2 below. 
58 Shetland Isles Council and NAFC Marine Centre, University of the Highlands and Islands, Shetland Islands Marine Spatial Plan, Fourth Edition, 2015, Chapter 7.

${ }^{59}$ Scotland's National Marine Plan, ch. 7. Scotland's Marine Atlas provides detailed and up-to-date information on production values and employment, Scottish Government, Scotland's Marine Atlas,

http://www.gov.scot/Topics/marine/education/atlas. The industry is currently dominated by the farming of

Atlantic salmon, there is also significant rainbow trout and mussel production. Brown trout, sea trout, halibut, Artic char, oysters and scallops, as well as seaweed are also farmed, Scotland's National Marine Plan, Para 7.3 p 52.

${ }^{60}$ Scottish Parliament Rural Affairs and Connectivity, 'Salmon Farming in Scotland' Report 27.11.18 para 110.

${ }^{61}$ Scotland's National Marine Plan, para 7.11.

${ }^{62}$ Scotland's National Marine Plan, Map 6 Guidance on the Location of Marine Fish farms. Locational Guidelines: finfish and shellfish sectors Marine Scotland Science (Scottish Government), 2016.

${ }^{63}$ This is the North and East coast of Scotland to safe guard migratory fish species.

${ }^{64}$ The Scottish Government, Scotland's National Marine Plan, Marine Planning Policy chapter 3 p. 50.

${ }^{65}$ Marine Scotland Science 2017.

${ }^{66}$ Scottish Government, National Planning Framework (2014) and Scottish Planning Policy (2014).

${ }^{67}$ See the Malawi principles nr 7; “'The ecosystem approach should be undertaken at the appropriate spatial and temporal scales".

${ }^{68}$ See sec. 3 on MSP.

${ }^{69}$ Ocean Wind Report, G. Bartnes (ed.), Havvind - forslag til utredningsområder, The Norwegian Water Resources and Energy Directorate, Oslo 2010. The selection was based on wind resources, sea depth, power transmission, supply and market relationship, environmental and land use interests at sea, Ocean Wind Report, sec. 4.6.4.

${ }^{70}$ Scotland's National Marine Plan: A Single Framework for Managing Our Seas (Scottish Government 2015)

Chapter 11.

${ }^{71}$ See footnotes 123-25.

${ }^{72}$ As defined by The United Nations Educational, Scientific, and Cultural Organization (UNESCO), Marine Spatial Planning.

${ }^{73}$ Directive 2014/89/EU (MSP). For EEA, see footnote 36.

${ }^{74}$ Directive $2009 / 28 / \mathrm{EC}$ on the promotion of the use of energy from renewable sources.

${ }^{75}$ Directive 2008/56/EC (MSFD), Articles 1(3) and 3(5). Directive 2000/60/EC (WFD), Art. 4. Directive

2014/89/EU (MSP) Art. 5(1). For EEA, see footnote 36.

${ }^{76}$ Directive 2014/89/EU (MSP) Art. 5(1).

77 The Aarhus Convention; Convention on access to information, public participation in decision-making and access to justice in environmental matters, 25 June 1998, 2161 UNTS 447.

${ }^{78}$ The North-East Atlantic Environment Strategy, Strategy of the OSPAR Commission for the Protection of the Marine Environment of the North-East Atlantic 2010-2020 (OSPAR Agreement 2010-3), Part II - The Thematic Strategies, p. 12, 4.

${ }^{79}$ S.E. Schütz, Marine Spatial Planning - Prospects for the Arctic, Arctic Review, 9 (2018), 44-66, https://doi.org/10.23865/arctic.v9.899, p. 45.

80 On third party access for developers of offshore oil and gas fields to upstream infrastructure for the purpose of transporting and processing hydrocarbons, see for Scotland, Oil \& Gas Authority, Third party access, https://www.ogauthority.co.uk/regulatory-framework/powers-sanctions-guidance/third-party-access/, for Norway in particular The Norwegian Petroleum Act, Lov 29.11.1996 nr. 72 om petroleumsvirksomhet, sec. 4-8, and subsequent regulation.

${ }^{81}$ Refers to integrated farming of several species from different trophic levels in close proximity, see P Kleitou, D

Kletou, J David, Is Europe ready for integrated multi-trophic aquaculture? A survey on the perspectives of European farmers and scientists with IMTA experience. Aquaculture, Volume 490, 1 March 2018, Pages 136-148.

${ }^{82}$ First update of the Management Plan for the Barents Sea - Lofoten Area.

${ }^{83}$ Scotland's National Marine Plan, A Single Framework for Managing Our Seas, Scottish Government 2015, Gen.

4, Co-existence.

${ }^{84}$ Ny vekst, stolt historie, Regjeringens havstrategi 02/2017, p. 35.

${ }^{85}$ Directive 2000/60/EC, the Water Framework Directive (WFD), is implemented under the land use planning system, formally as a regional thematic plan, see sec. 4.2 on regional planning.

${ }^{86}$ This was presented as a proposition to the Parliament St.prp. nr. 32 (2006-2007) Om vern av villaksen og

ferdigstilling av nasjonale laksevassdrag og laksefjorder, and followed by implementation in excisting legislation. The protected fjords and rivers represent approx. $3 / 4$ of the national wild salmon resource, see St.prp. nr. 32 (2006-2007) p. 7.

${ }^{87}$ Ibid Ch. 7 and p. 84

${ }^{88}$ St. prp. nr. 32 s 44, see Forskrift 22.06.2009 nr. 961,om særskilte krav til akvakulturrelatert virksomhet i eller ved nasjonale laksevassdrag og nasjonale laksefjorder, sec. 6 on duty to move facilities.

${ }^{89}$ Meld. St. 16 (2014-2015), Forutsigbar og miljømessig bærekraftig vekst i norsk lakse- og ørretoppdrett. 
${ }^{90}$ Forskrift 16.01.2017 nr. 61 om produksjonsområder for akvakultur av matfisk i sjø av laks, ørret og regnbueørret, (Regulation 16.01.2017 no. 61 on production areas for aquaculture of food fish in the sea of salmon, trout and rainbow trout), (Production areas regulation) see sec. 2, 1 para.

${ }^{91}$ Production areas regulation, annex I. The zones are now limited to 30 nautical miles beyond the baselines in the south and $20 \mathrm{~nm}$ in the north, thus, future aquaculture production further out in the open sea, is encompas sed.

92 Production areas regulation, sec. 4.

93 The critique was presented in the processes of public hearing of the proposals on new regulations on production areas, dating to the years 2016-2017, available at https://www.regjeringen.no/no/dokumenter/horingsbrev-omfleksibilitet-produksjonsomrader/id2524267/.

${ }^{94}$ Ibid.

95 The Norwegian Planning and building Act (PBA); Lov 27.06.2008 nr. 71 om planlegging og byggesaksbehandling.

${ }^{96}$ See The Norwegian Planning and building Act sec. 1-2. This is due to the implementation of the Water

Framework Directive, Directive 2000/60/EC, under the EEA-agreement.

${ }^{97}$ PBA sec. 6-1

${ }^{98}$ Kommunal- og moderniseringsdepartementet, Nasjonale forventninger til regional og kommunal planlegging.

Vedtatt ved kongelig resolusjon 12. juni 2015, at p. 17

${ }^{99}$ Letter from the Fisheries- and coastal dep. to the Directorate of fishries and The Food Safety Authority, 8. april 2008.

${ }^{100}$ Regional Kystsoneplan for Sunnhordland og ytre Hardanger, 2017. See aslo P.B. Sørdahl, A. Solås, I. Kvalvik and B. Hersoug, Hvordan planlegges kystsonen? Kartlegging av gjeldende planpraksis etter plan- og bygningsloven i sjøområdene, Rapport 15/2017, Nofima, juni 2017, p. 25.

${ }_{101}$ Regional Kystsoneplan for Sunnhordland og ytre Hardanger, 2017.

102 PBA sec. 8-2.

103 Pollution Control Act; Lov 13.03.1981 nr. 6 om vern mot forurensninger og om avfall, sec. 11. Aquaculture Act; Lov 17.06.2005 nr. 79 om akvakultur, sec. 15.

104 PBA sec. 5-4.

105 P.B. Sørdahl, A. Solås, I. Kvalvik and B. Hersoug, Hvordan planlegges kystsonen? Kartlegging av gjeldende planpraksis etter plan- og bygningsloven i sjøområdene, Rapport 15/2017, Nofima, juni 2017, p. 12. Sea use planning is merely an option for the municipalities. Today, only five of 275 coastal municipalities have no plan for sea areas. I.E. Myklebust, Aquaculture law and administration in Norway in Aquaculture Law and Policy, N. Bankes, I. Dahl and D. L. VanderZwaag (ed) p. 345.

106 PBA sec. 11-6.

${ }_{107}$ Scottish Parliament Rural Affairs and Connectivity Committee Report, Salmon Fishing in Scotland, 2018.

108 Scotland's National Marine Plan, Para 7.5 p 53 and An Assessment of the Benefits to Scotland of Aquaculture, Imani and SRSL, 2014.

109 Town and Country Planning (Scotland) Act 1997 as amended by the Planning etc. (Scotland) Act 2006.

110 Scottish Government, The Relationship between the Statutory Land use Planning System and Marine aplnning and licensing (Planning Circular 1/2015), June 2015, para 94.

${ }^{111}$ Scotland's National Marine Plan, Para 7.27 p 57. But it is noted that this should not necessarily be taken to mean beyond $12 \mathrm{~nm}$ and in most cases would be operating within the $3 \mathrm{~nm}$.

112 Reflected in the Code of Good Practice for Finfish Aquaculture (CoGP) by a specific national treatment strategy, see Scotland's National Marine Plan, para 7.12.

113 Aquaculture and Fisheries (Scotland) Act 2013 Chapter 3.

${ }^{114}$ Letter from Petroleum Directorate to the The Norwegian Water Resources and Energy Directorate, datert $09.02 .2017, \mathrm{p} 2$.

${ }^{115}$ K. Nybakke (ed.)/K.S. Berg, M. Carlsen, T. Eirum, S.B. Jakobsen, N.H. Johnson, S.K. Mindeberg, K. Nybakke, G.S. Sydness, Havvind - Strategisk konsekvensutredning, Rapportnummer 47-12, The Norwegian Water Resources and Energy Directorate, Oslo, 2012 (2012 SEA).

1162012 SEA.

1172012 SEA, sec. 17.1.

1192012 SEA, sec. 25. Only one area in the area of the Barents Sea management plan were recommended opened, 'Sandskallen - Sørøya Nord`, outside the municipality of Hammerfest. in accordance with the OEA, the 2012 SEA was circulated for comment and presented for public scrutiny in 2013. The Municipality of Hammerfeststated unanimous that the county council were negative to the opening of the area Sandskallen, and argued for a land-based wind farm, already planned and rejected by NVE. OED, Public scrutiny, 2012 SEA, 04.01.2013. Hammerfest Kommune, høringsuttlaaelse strategisk Ku - Havvind Sandskallen Sørøya nord, 17.04.2013

120 The Government aims to open some areas offshore for demonstration projects, see press release 13.12.2017.

121 OED, Press release, 13.12.2017 After consultation and an evaluation, among others of lowered construction costs, it is stated that the recommendations given in $2012 / 2013$ still are valid. ${ }^{121}$ It is stated that 'Utsira nord' (floating constructions) and either `Sørlige Nordsjø` I or II (relevant for both floating and seabed fixed constructions) can be opened first. 
122 Scotland's National Marine Plan, 11.1 p. 81, setting ambitious targets for renewable energy by aiming to generate the equivalent of $100 \%$ of Scotland's electricity demand from renewable resources by 2020 and to deliver an $80 \%$ reduction in greenhouse gas emissions by 2050.

123 Scotland's National Marine Plan, Chap 11, Part 1 objective 1.

124 Ibid, Chap 11, Part 1 objective 2.

125 Ibid, Chap 11, Part 1 objective 6.

${ }^{126}$ Ibid, 11.11 p. 83.

127 Ibid, 11.12 p. 83.

128 Ibid, 11.13 p. 81.

${ }^{129} \mathrm{Ibid}, 11.26$ p. 85.

${ }^{130} \mathrm{Ibid}, 11.31$ p. 86.

131 Ibid, 11.36 p. 86.

132 The preamble to the Aarhus-convention thus recognizes that "... the public needs to be aware of the procedures for participation in environmental decision-making, have free access to them and know how to use them". Access to justice, through either to appeal, challenge a decision or access to courts, is likewise a fundamental value.

133 The Norwegian constitution, sec. 105.

${ }^{134} \mathrm{~J}$. Ebbesson, The rule of law in governance of complex socio-ecological changes, Global Environmental Change, 20 (2010) 3, 414-422, https://doi.org/10.1016/j.gloenvcha.2009.10.009, p. 418.

135 The Norwegian Aquaculture Act sec. 4, 2. para. The license is registered in the aquaculture register, see, sec. 18, first paragraph.

${ }^{136}$ Norwegian Food safety Act; Lov 19.12 .2003 nr. 124 om matproduksjon og mattrygghet mv. Norwegian Animal Welfare Act; Lov 19.06.2009 nr. 97 om dyrevelferd.

137 This is a general presumption in the tax-regime, see Skatteetaten Skatt-ABC 2018, sec 7.1.

138 Aquaculture Act sec. 6.

139 The growth is distributed in two rounds, first at a fixed price, the rest at auction, contributing to the 2016

established Aquaculture Fund, of which 80 per cent is distributed annually to municipalities and counties with aquaculture.

140 O. K. Fauchald, Juridisk utredning angånde produksjonsomradeforskriften og kvalitetsnormen for villaks, til Norske Lakseelver, 4. Nov. 2017.

141 The invitation was open until November 2017.

142 Per January 8, 2017 there were 38 applications received.

143 In the ongoing evaluation, as for now a few applicants have been accepted, among others an ocean cage concept based on offshore oil technology, and an ocean farm resembling a ship, with possible significant effects on the production capacity in Norway by 2020, Ernst and Young, The Norwegian Aquaculture analysis 2016.

144 I.E. Myklebust, Aquaculture law and administration in Norway in Aquaculture Law and Policy, N. Bankes, I. Dahl and D. L. VanderZwaag (ed) p 345.

145 Ibid.

146 Nature Diversity Act sec. 7.

${ }^{147}$ Nature Diversity Act sec. 8-12.

148 Marine Scotland, 'Marine Licensing in Scotland'.

149 Ibid.

${ }^{150}$ Marine Scotland, 'Seal Licensing'.

151 Water Environment (Controlled Activities) (Scotland) Regulations 2011.

152 The Aquatic Animal Health (Scotland) Regulations 2009.

153 Aquaculture and Fisheries (Scotland) Act 2013 (asp 7).

${ }^{154}$ Scottish Executive Development Department, 'The Extension of Planning Controls to Marine Fish Farming' (Consultation paper, Scottish Executive 2000).

155 Water Environment and Water Services (Scotland) Act 2003. The change was initially part of the legal regime which implemented the EU Water Framework Directive.

156 A. Slater, Aquaculture and the law: United Kingdom and Scotland in: N. Bankes, I. Dahl and D.L. VanderZwaag (eds.) Aquaculture Law and Policy, Edward Elgar, Cheltenham/Massachusetts, 2016, pp. 412-431, p. 430.

${ }^{157}$ Local Development Plans produced by relevant local planning authorities provide locational local policy in relation to aquaculture development.

158 Town and Country Planning (Scotland) Act 1997 (UK), s. 31A. There are now extensive permitted development allowances, i.e. changes that allow development without planning permission.

159 Planning etc. (Scotland) Act 2006 Part 2 and Scottish Government, The Relationship between the statutory Land Use Planning System and Marine Planning and Licensing (Planning Circular 1/2015, June 2015) para 5.

160 Planning etc. (Scotland) Act 2006, for EIA see Environmental Impact Assessment (Fishfarming in Marine Waters) Regulations 1999, SI 1999/369. Some decisions are delegated to Officers depending on the Delegation Agreement for the Local Authority.

161 Town and Country Planning (Scotland) Act s. 25(1). 
162 Marine (Scotland) Act 2010

163 Prior to 2007 they were regarded as temporary and once the time period had expired a further approval was required.

${ }^{164}$ Highland, Shetland, Orkney, the Western Isles and Argyll and Bute Councils.

165 Water Environment (Controlled Activities) (Scotland) Regulations 2011.

166 Scottish Parliament, Rural Affairs Committee Report 'Salmon Farming in Scotland' Recommendation 1 27.11.18.

167 Scottish Parliament, Rural Affairs Committee Report 'Salmon Farming in Scotland' Recommendation 2 27.11.18.

168 The Norwegian Ocean Energy Act sec. 3-1 (production facilities) and sec. 3-2 (infrastructure). The license is given by the state agency The Norwegian Water Resources and Energy Directorate.

${ }_{169}$ The Norwegian Ocean Energy Act sec. 2-2, first para. state that "The King in Council may determine that a closer, permanent demarcation area covered by sections 1-2 shall be opened with a view to granting a license pursuant to section 3-1." It is from this not explicit that an application cannot be granted even if the application is outside the opened area. Still, from the preparatory works, normally with high impact on the interpretation in the Norwegian Supreme Court, it follows that according to the first paragraph "no one is entitled to have a licence application for production facilities considered if the application is due to an area that is not open", Ot.prp.nr.107 (2008-2009) Om lov om fornybar energiproduksjon til havs (havenergilova) p. 80-81.

170 Ocean Energy Act sec. 10-2.

171 Ibid sec. 3-4, 1 para nr 5.

172 Ibid sec. 3-5, 2 para.

173 Under the Scotland Acts 1998 and 2016, the Scottish Government have executive power to make decisions about offshore energy, under the existing legislation, but it cannot repeal the Electricity Act 1989 or pass new legislation.

174 The Crown Estate Offshore Energy Leasing Rounds

175 https://consult.gov.scot/marine-scotland/offshore-wind-scoping/

176 Energy Act 2004 s. 93.

177 Electricity Act 1989 Paragraph 3 of Schedule 9.

178 Ibid.

${ }^{179}$ Electricity Act 1989 sec. 36B.

${ }^{180}$ Ibid sec. 36.

181 Ibid.

182 Marine (Scotland) Act 2010 s. 15(3).

183 The Scottish Ministers must, when exercising any function that affects the Scottish marine area must act in the way best calculated to mitigate and adapt to climate change so far as is consistent with the purpose of the function concerned. Climate Change (Scotland) Act 2009 as amended and under part 2 of the Marine (Scotland) Act 2010.

184 The Marine Works (EIA) Regulations 2007 (as amended).

185 Joint Nature Conservation Committee, Scottish Natural Heritage, Scottish Environmental Protection Agency and Local Planning Authorities under the Town and Country Planning (Scotland) Act 1997 as amended by the Planning (etc.) Scotland Act 2006., plus Special Areas of Conservation and Special Protected Areas issues under the Birds and Habitats Directives. Statutory consultees for Marine License applications (under the Marine Works (Environmental Impact Assessment) (Scotland) Regulations 2017) are any relevant local planning authority, SNH, SEPA, Historic Environment Scotland, and any relevant authority. Additional statutory consultees under the Marine Licensing (Consultees) (Scotland) Order 2011 are the Commissioners of Northern Lighthouses, the Maritime and Coastguard Agency ("MCA"), see Marine Scotland, Offshore Energy Licence and Consents Guidance, 2018.

186 RSPB v. Scottish Minsters [2017] CSIH 31.

187 Electricity Act 1989 s.36 B.

188 Marine (Scotland) Act 2010.

189 In Norway under The Norwegian Planning and Building Act, dispensation rules have become stricter from 2008. In the preparatory works for the new Norwegian Planning and Building Act, NOU 2001:7 Bedre kommunal og regional planlegging, the former dispensation regulation is discussed. It is stated that in many cases, the dispensation practice is unnecessarily extensive, that land use in some places is governed more through individual dispensation decisions than through plans, and that it "could at worst undermine the plan itself and the concerns it should take", and that this also challenges important values of the planning system itself, see p. 91. Particularly the coastal zone, and dispensations from the general ban on any building in the area between the ordinary high water mark and up to $100 \mathrm{~m}$ inland from the shoreline, is discussed, p. 92. Today Norway has more nuanced regulation for the coastal zone, see S.E. Schütz, I.E. Myklebust, Coastal zone management - between politics and law: new guidelines for differentiated management of the shore zone in Norway, Local Environment: the International Journal of Justice and Sustainability, 21 (2016) 2, pp. 189-201, https://doi-org.pva.uib.no/10.1080/13549839.2014.932338.

190 The Norwegian Petroleum Act, Lov 29.11.1996 nr. 72 om petroleumsvirksomhet.

191 These are facts like reduction in the costs of offshore equipment, improvements in technology and the politically motivated decision from 2010 onwards to reduce subsidies for renewable energy in the UK.

192 Beyond Markets and States: Polycentric Governance of Complex Economic Systems Prize Lecture, December 8, 2009 by Elinor Ostrom p 409. 